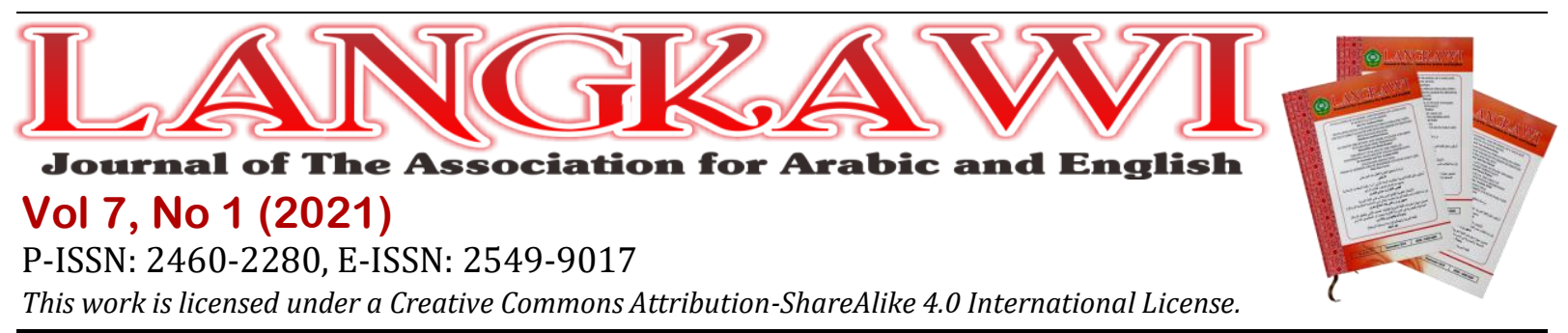

\title{
Audio Speed Changer Application: Advancing Students' Listening Comprehension
}

\section{Nur Fadillah Nurchalis}

Sekolah Tinggi Agama Islam Negeri Majene, Indonesia. Email: nurfadillahnurchalis@stainmajene.ac.id

\begin{tabular}{|c|c|}
\hline ARTICLE INFO & ABSTRACT \\
\hline Keywords: & As a receptive skill, listening is very influential for students' language \\
\hline Audio; Speed; Listening & development. Unfortunately, it often becomes the most challenging \\
\hline Comprehension & $\begin{array}{l}\text { skill in learning a foreign language for students. One of the obstacles } \\
\text { experienced by students of the English Study Program of STAIN }\end{array}$ \\
\hline $\mathrm{Hoz}$ & Majene is the speed of spoken native language. This research aims to \\
\hline Nurchalis, N. F. (2021). & prehension by using Audio Speed \\
\hline Audio Speed Changer & Changer (ASC). This research applied classroom action research of \\
\hline Application: Advancing & Kammis and Taggart model. It used four phases, namely planning, \\
\hline Students' Listening & ervation, and reflection. There were \\
\hline Comprehension. & $\begin{array}{l}\text { ins } \\
\text { she }\end{array}$ \\
\hline Langkawi: Journal of The & $\begin{array}{l}\text { sheet, and interview. The test was used to measure students } \\
\text { achievement. An observation sheet was used to identify speed }\end{array}$ \\
\hline $\begin{array}{l}\text { Association for Arabic and } \\
\text { English, } 7(1), 1-12 \text {. }\end{array}$ & $\begin{array}{l}\text { development. An interview was used to gain information about } \\
\text { students' responses to ASC application. There were two cycles in this }\end{array}$ \\
\hline DOI & research. The success of a cycle was determined by using two criteria \\
\hline http://dx.doi.org/ & as follow: (1) students' mean score had to be higher than 75 points in \\
\hline 332/1kw.v7i1.2154 & the last phase of a cycle; (2) there should be at least $80 \%$ of students \\
\hline & $\begin{array}{l}\text { who got at least } 15 \text { points for their final scores. This research found } \\
\text { that students' scores dominated the poor category in the first cycle, but }\end{array}$ \\
\hline History: & it reduced 35.32 points of its percentage in the second cycle. Students' \\
\hline 20-09-16 & scores in the second cycle dominated enough categories. ASC \\
\hline Accepte & application was able to overcome one of the students' problems in \\
\hline Published: & listening comprehension. \\
\hline
\end{tabular}

\section{Introduction}

Listening is a language skill that is developed firstly by humans (Renukadevi, 2014). Before a newborn baby learns to speak and read, he first listens to the sounds or voices around him to internalize the linguistic input (Cahyono, BY and Widiati, 2009). In communication, listening skill is crucial. It is the ability to receive and interpret messages from a speaker accurately. Listening is classified as a receptive skill because people receive input like sounds through their sense of hearing. A good listening skill leads to effective communication. Misunderstanding between two people may happen if one does not have the effective listening ability (Maisarah, 2016).

Hearing and listening are different. Hearing is an action of perceiving sounds with ears, while listening is an act of paying attention to what people hear (Hornby, 1995). Hearing refers to physical ability. It is effortless. Every sound goes to the ears; then, it is received passively in the brain.

In contrast, listening refers to a mental skill. It requires a thought process. Listening happens when people want to catch the meaning of the sounds they hear. They process the delivered message by interpreting it in their brain. In a listening 
activity, of course, there is a hearing activity, but in a hearing activity, there is not necessarily a listening activity. Thus, to create effective communication, people need listening skills, not hearing skills.

Listening mainly contributes to language acquisition and language learning. The sounds, intonations, rhythm, and stress of the language can only be adjusted through listening. Listening to a target language has the power to improve learners' language ability (Renukadevi, 2014). When learners can distinguish the sound of each word, they can identify what words are spoken. For example, learners can differentiate between sounds of the word 'sing' and 'thing'. If a learner is confused by a sound that he listens, he usually clarifies it. In the process of clarification, the learner may acquire a new vocabulary. This case shows that listening has an impact on students' vocabulary enrichment. Listening enables learners to understand the spoken words.

A good listening skill also affects students' speaking ability. Listening and speaking cannot be separated. Speaking is a product of imitating what is heard or listened. Biology experts and educators agree that speaking follows listening and listening follows hearing (Gallagher, 2015). It means that to guarantee learners' speaking ability, their listening ability has to be guaranteed first. In research, It was found that English Department students made several mistakes in pronouncing consonant sounds (Anggraini, N and Istiqomah, 2019). It happened because students only pronounced the words that they heard or listened to around them. The teachers need to produce the correct pronunciation in the classroom to get the right input from their ears. The correct input from listening will influence the right learners' speech production.

Teaching a listening skill in the classroom is pivotal to develop learners' language proficiency. Rost emphasizes its reasons: firstly, to begin learning, learners need to understand the correct input. Secondly, understanding the target language requires authentic spoken language. Only through listening can EFL learners get acquainted with the authentic target language. Thirdly, listening exercises are required to draw learners' attention to advanced forms such as grammar, vocabulary, and interaction patterns (Rost, 1991). Listening skill is a primary skill for learners to learn a new language. It shapes output and makes advancement in verbal language proficiency.

Nevertheless, in EFL context, listening skill is often underestimated since it is assumed that people learn listening automatically. People do not need extra efforts to learn, like speaking (Ulum, 2015). Based on an interview session with three English teachers in MTs YMPI Rappang a few months ago, all of them said that the learning portion of speaking, reading, and writing is often more than listening in the classroom. In many course books, listening also is not significant. According to Abu-Snoubar there are two reasons why listening skills is lacking attention in the classroom. Firstly, several English teachers deeply believe that teaching another receptive skill, reading, can replace listening. They consider that reading is also an input skill. Secondly, teachers encounter some challenges in teaching and testing listening skills. It demands small classes and special equipment like speakers, audio players, even listening laboratories (Abu-Snoubar, 2017). Those reasons drive listening inaccessible in EFL classrooms. 
In addition, Listening skill is not easy for EFL learners. In other words, EFL learners work hard to learn a listening skill (Amal, 2019). Listening to a native language and a foreign language has different challenges. Listening to a native language is flowing because everyone can listen to original spoken words in their daily activities. In contrast, listening to a foreign language is demanding. EFL learners only listen to authentic materials in certain situations, such as learning in the classroom, watching a movie and listening to English songs or speeches. They need repetition and habituation for perfection. Therefore, to learn the listening skill of a foreign language, there are several steps that students need to follow, starting from the easiest step.

In teaching and learning listening, Wolvin and Carolyn mention that there are five steps of listening. The first is discriminative listening. It is the fundamental step. Learners learn how to distinguish sounds in order to understand their meaning. Here, language learners try to discern between the phonemes of the target language. The second is comprehensive listening. In this step, language learners attempt to gain information and understand what is spoken. The third is appreciative listening. When learners can comprehend the main idea of spoken words, they then enjoy what they listen to like this step. The fourth is Empathetic listening. In this step, learners can get in touch with the speaker's expression. The last is critical listening. It is beyond understanding the meaning. In this step, learners can evaluate or judge what the speaker expresses. It is categorized as the most complex listening form (Wolvin and Carolyn, 1982). Learners learn those steps in order based on the level of difficulty.

As stated in the syllabus of the listening course for English Education Program students in STAN Majene, the listening subject consists of three levels. In the first level of the listening course, the materials are concerned with discriminative and comprehensive listening. Students are trained to discriminate sounds on the recording. Understanding spoken words of other languages, students must be able to identify the differences in the sounds. In addition, they are also trained to identify the main idea and investigate both stated and unstated detail information spoken on the recording. Before they move to the next level, they have to master those materials. Listening comprehension ability is required to master in order that students can join the upcoming level. The fact, many students had difficulties following the subject.

According to Bingol et al. 1, new language learners have several difficulties in listening comprehension: the first is the quality of recorded materials. The low quality of audio materials and sound system disturb students' concentration, inhibiting learners' comprehension in listening. The second is cultural differences. Cultural knowledge of the language has a meaningful impact on learners' understanding. Learners should get acquainted with it. Listening material should not be different in a culture so that learners have prior knowledge to be associated with what they listened to. The third is the accent. The different accent from what learners usually listen (their teachers' accent) can cause significant problems in listening comprehension. The fourth is unfamiliar vocabulary. Learners are more interested and motivated when they know the meaning of the words. It gives a positive contribution to their listening comprehension ability. The last is length and speed of listening (Bingol et al., 2014). 
Listening to passages became difficult because of their speed (Underwood, 1989). When audio players run too fast for students, they may have serious barriers to understanding what the speaker said \{Formatting Citation\}. Nevertheless, every class faces different reasons for difficulties.

Based on his observation in his research, Putra classified listening comprehension problems into two. The first was the problems from students as listeners. Students had difficulty comprehending the English spoken words because they found unfamiliar words, phrases, or intonation patterns; they could not differentiate sentence patterns and discourse markers, and they could not follow native speakers' tempo. The second was the problem with listening materials. Students faced barriers in listening comprehension because the dialog or monologue on the recording was too long. They needed time to think and rethink what they listened. The length of the recording had to be dealt with students' level.

In his research, he offered drilling techniques to overcome those problems. His research found that the drilling technique improved students' listening comprehension in full features of micro skill types of listening comprehension. The features are recognition sentence pattern, referential info, recognition discourse marker, and recognition intonation pattern. The improvement of students' listening comprehension happened particularly in recognition intonation patterns (Putra, 2019). However, the drilling technique has a negative aspect. It takes more time, especially if the recording that students listen has a long duration and if the teacher is confused remembering in what minutes the recording should be repeated. The researchers above found the same problem that students face in listening comprehension, namely speed.

Based on the teacher's experiences in the listening class, students always asked the teacher to repeat the recording many times when the teacher played the recording. Repeating the recording again and again with the same speed is still challenging for students. The class became not ineffective since one material took time because of the repeated recording. Students mostly understood the spoken word quickly when the teacher repeated it herself; the teacher pronounced the words slowly. Students often said that they could understand the recording if it was slow. They were confused about what the speaker said on the recording since he spoke too fast. They could not guess what words he spoke because the speaker linked the words he pronounced. It became unclear for the students. Considering it, what actually students faced in the listening class was that the speed of recoding. If this problem persists, students are not able to follow the class. Data from the pra-e-research of this study showed that students' mean scores were only 57 points for the previous listening test administered by the researcher. None of them reached the minimum standard score. It means that repeating recording often at the same speed or tempo did not help students improve their listening comprehension. Therefore, the teacher also acted as the researcher interested in using the audio speed changer application to mediate students with their barriers.

Audio Speed Changer (ASC) is a tool to change the speed of audio or playback. In other words, it is an application that everyone can use to manage the audio or playback tempo as they need. They can change the audio from slower to fast frequency. Some people use it for vocal training, but it also can be used for language 
learning (ASC, 2018). ASC supports various formats such as mp3 and mp4. It can be access through a website and an application on android. In order to help the teacher use this application practically in language classes, it is highly recommended for language teachers to download the application on their mobile phone through 'App Store' for iPhone or 'Play store' for android. If ASC has been available in language teachers' mobile phones, language teachers can flexibly adapt the audio speed based on the students' needs in a listening class.

The way to use ASC is also straightforward. If teachers access it from the web, there are four steps that they need to follow. First, select the audio file. Second, select speed changing. Third, select the output format. The last is converting the file (ASC, 2018). If teachers use it on iPhone or android, they can use it simpler. Teachers only need to click the ASC application and choose the audio file. After that, they can choose a percentage of the audio speed and play it. Teachers can easily change the percentage of audio speed without changing the actual speed of an audio file. If the students are at a low level, the speed should be set slower, but if the students are at up level, the speed may be set at $100 \%$ speed. It can accommodate students' needs from a different level. The usage procedure is also not complicated for teachers, reducing serious reasons that inhibit listening teaching.

Following the phenomenon above, this study would like to solve students' listening problems in a listening class of STAIN Majene using Audio Speed Changer (ASC). This study aims to advance students' listening comprehension by using the Audio Speed Changer application in android. This study's results are expected to contribute to practical activities in language learning, especially in listening classes. For instance, teachers can help students to improve their listening comprehension by adjusting audio recording speed with students' levels in listening classes. Students also can learn listening courses independently through their mobile phones by only downloading the application of ASC. In addition, this study is expected to become a reference for other researchers to continue other research related to this study.

\section{Method}

This study applied Classroom Action Research (CAR) specific to the spiral model (Kemmis \& Taggart, 1988). In this study, the lecturer acted as the researcher too. She researched in her classroom. Nevertheless, she also collaborated with other lecturers who helped her as observers. They observed the activities during the usage of the Audio Speed Changer application in the listening class. The issue of this study was a problem faced by students in the listening class. Repeating audio files for many times with the same speed is a former method that the lecturer used. That method did not work well in helping students to gain good comprehension in a listening class. By considering advantages offered by the Audio Speed Changer application, the researcher used this application as a new way to help students to overcome their obstacles in the listening class. The subject of this study was freshmen of Class B of English Education Program of STAIN Majene in the academic year 2019/2020. The class consisted of 28 students.

This Classroom Action Research was conducted in four phases for one cycle. The first phase was planning. In this phase, the researcher designed her lesson plan, teaching materials, and prepared teaching aids. The second phase was 
implementation. In this phase, the researcher put her plans into actions. The researcher attempted to make the actions similar to the planning in the first phase, namely playing the recording at various speeds based on students' ability. The researchers increase the speed if the students can follow the previous speed. It continues until the students' ability reaches the ideal speed. The third phase was observation. In this phase, the observers took notes and checked the observation sheets to record activities which occurred during the class. Observers check-in what speed students can in with the recording. Because this study implemented Kemmis and Taggart model (Kemmis \& Taggart, 1988), the second and the third phases were conducted at once. The researcher who implemented the planning worked at the same time as the observers who recorded the activities. The last phase was reflection. In this phase, the researcher evaluated the results of implementation and observation. Those phases are described in the figure 1.

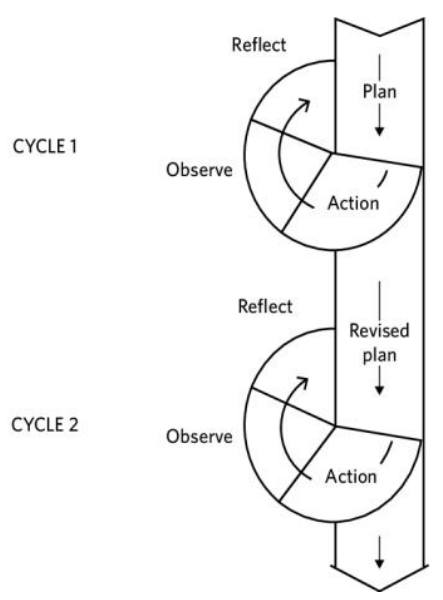

Figure 1. Phases of Spiral Model by Kemmis and Taggart in CAR

There were three kinds of instruments used in this research. Firstly was a listening test. It aimed to measure the number of points or students' scores. The test form was multiple choices consisted of 20 numbers. The test contained five listening skills, namely determining the main idea, inference, detailed information (both stated and unstated), suggestion or advice, and purpose of the talk. Secondly was the observation sheet. It was used to see or to notice: (1) in what speed of recording that students were able to follow the class every meeting; (2) the number of repetitions of the recording. Thirdly was interview question list. It meant finding a student's response about their learning progress after teaching listening skills by using audio speed changer application.

Criteria of success determined the number of cycles that were implemented. There were two success criteria: (1) students' mean score had to be higher than 75 points in the last phase of a cycle; (2) there should be at least $80 \%$ of students who got at least 75 points for their final scores. When the students met those criteria, the implementation was categorized as successful. To classify students' score, the researcher developed criterion of interpretation score based on criterion of the score for standard minimum score "75" determined by Ministry of Education and Culture (Kementrian Pendidikan dan Kebudayaan, 2017) as shown by table 1. 
Table 1. Criterion of Interpretation Score

\begin{tabular}{cc}
\hline Interval Score & Category \\
\hline $93-100$ & Very Good \\
$84-92$ & Good \\
$75-83$ & Enough \\
$66-74$ & Poor \\
$<65$ & Very Poor \\
\hline
\end{tabular}

\section{Findings and Discussion}

This research applied two cycles in orderly since the students' scores did not meet the two success criteria in the first cycle. Therefore, the second cycle is conducted. Because in the second cycle, the students' score had been meeting the criteria of success determined in this research, there was no more the third cycle as its sequence. Two cycles were enough to address students' problems in listening comprehension session by using ASC application. Those two cycles are described as follow:

\subsection{The First Cycle}

Considering the issue that learners encountered in listening class, in the first cycle, the researcher designed a lesson plan by choosing Audio Speed Changer (ASC) application as a media to help learners improve their listening comprehension. During the implementation, the teacher also acted as the researcher played the recording starting from $60 \%$ tempo until $100 \%$ per meeting. Based on the data in the observation sheet, students were able to catch the meaning of what they listened if the speed of the recording at about $60 \%-80 \%$. It is because they could listen clearly to the words spoken by the native speakers on the recording. In that range of speed, they could answer questions delivered by the teacher based on the recording particularly about main idea, inference, suggestion or advice, and purpose of the talk. They could also find information from the recording, either stated or unstated information.

However, once the speed of a recording at about $81 \%$ or $100 \%$, they could not understand the main idea of the recording and determine inference, suggestion, details, and purposes of the talk. Their face expressed confusion after listening to a recording at that level of speed. It was unclear for them since it was too fast. They could not keep up with that level of speed. They were overwhelmed to determine what the main idea of the recording was. They asked the teacher to reduce the tempo by about $70 \%$ to $80 \%$ maximally. They could not listen while thinking simultaneously at $90 \%$ to $100 \%$ speed of the recording. They needed more time to think after listening; therefore slower speed of the recording contributed to improving their comprehension of English spoken monologue or dialogue. In the final phase of cycle one, students were asked to answer 20 numbers of multiple-choice tests to measure students' progress. After calculated the answer sheet, the distribution of students' score is presented on table 2 . 
Table 2. Distribution of students' Score in cycle I

\begin{tabular}{cccc}
\hline Frequency & Percentage & Interval Score & Category \\
\hline 0 & $0 \%$ & $93-100$ & Very Good \\
0 & $0 \%$ & $84-92$ & Good \\
3 & $10.71 \%$ & $75-83$ & Enough \\
15 & $53.58 \%$ & $66-74$ & Poor \\
10 & $35.71 \%$ & $<65$ & Very Poor \\
\hline
\end{tabular}

Compared to the previous test data stated in the preliminary study, the students' mean score was improved from 57 points to 68 points. Students' mean scores increased 11 points. Nevertheless, the increase of students' scores still did not meet the criteria of success. Students' mean score has to be higher than 75, while in the first cycle students' mean score only 68 . In addition, another criterion stated that at least $80 \%$ of students have to get at least 75 points. Based on table 2 above, only $10.71 \%$ students reached that criterion. It means that students still had difficulties with the recording speed, even though the level of the problem had been lower than before. They needed more practice to listen to the recording at $81 \%$ to $100 \%$ speed. One cycle is not enough to address the students' barriers. There has to be a sequential cycle to follow.

In addition, based on the interview session in the reflection phase, $\mathrm{NH}$ stated that the slow tempo helped them understand English native sound recordings more easily. She added that she did not need to ask the teacher to replay the recording when the tempo was slowed since she listened clearly to what the speaker said on the recording. With a slow tempo, students find it very helpful to identify the words and the sentence structure spoken by the speaker to gain information from the speakers. When listening, noticing is necessary. Schmidt in Wong argues that noticing is a requirement of effective listening (Wong, 2015). When students notice, they have influenced the speed of input. It is very impactful for memory work. When their memory works, they can interpret the message delivered by native speakers. Hence, students do not need to replay the recording several times when they feel comfortable with that speed.

$\mathrm{NH}$ also said that she still needed to try to listen to various speeds so that she did not only rely on the slow tempo or slow speed of played recording. Students still encounter speed rate problems. They still could not comprehend the recording when it was played at $100 \%$ speed of English native speaker version. The frequency of practices has to be increased to make them more familiar with that speed. It is relevant to what Putra said that frequency of listening practices enables students to adapt to native speakers' speed (Putra, 2019). The more they practice, the sooner they would become more proficient. It was implied that students needed additional cycles to improve their ability in English listening comprehension. For those reasons, the teacher planned the second cycle.

\subsection{The Second Cycle}

After determining to continue the first cycle, the researcher focuses on improving students' listening ability in listening to a recording which speed is around 
$81 \%$ to $100 \%$. In the planning phase of cycle II, the researcher designed a lesson that emphasized playing the recording starting from $81 \%$ to $100 \%$ sequentially. In the implementation of each meeting, the students showed their progress. They were able to follow the played recording when the tempo was increased slowly. For instance, the researcher played a recording for part A with $81 \%$ speed. They could retell what they hear as well as answer the questions based on the recording. Then, the researcher increases the tempo to $83 \%$, the students could still keep up with that tempo. Once the tempo jumped three times, the students were overwhelmed. It means that the students needed slow treatment. They needed more time in the process. Even their improvement increased slowly, but it showed progress. Audio Speed Changer application works.

The data from observation sheet presented that students stayed focused on the recording when the speed was about 81-90. When the speed or tempo was increased to $91 \%-100 \%$, most of them still grumbled. They tried to keep it up, but they needed to write several points of what they listen. Without it, they found difficulties. It indicated that they still needed efforts to listen to English native speakers in 100\% tempo. They needed a lot of practice and habituation. The students could reach the progress for each meeting because they kept practice at home since they downloaded the ASC application on their mobile phone. It is the advantage of ASC application because it is easily accessible for students. They must not rely on their English teachers to play English recordings in a language laboratory.

In the final phase of cycle II, the researcher gave a test to students. The recording of the test consisted of a short conversation (dialogue) and a short monologue. The numbers of questions that students had to answer were 20. After checking the student's answer, it was found on table 3:

Table 3. Distribution of Students' Score in Cycle II

\begin{tabular}{cccc}
\hline Frequency & Percentage & Interval Score & Category \\
\hline 0 & 0 & $93-100$ & Very Good \\
0 & 0 & $84-92$ & Good \\
23 & 82.14 & $75-83$ & Enough \\
5 & 17.86 & $66-74$ & Poor \\
0 & 0 & $<65$ & Very Poor \\
\hline
\end{tabular}

Table 3 showed that the percentage of students who reached scores in intervals 75-83 increased from the first cycle. It increased by 71.43 points. In the first cycle, students' scores dominated in the poor category, but it reduced 35.32 points of its percentage in the second cycle. Students' scores in cycle II dominated in enough categories. In addition that None of students got very poor in cycle II. Students' mean score in cycle II was 75.51. Considering the criteria of success, cycle II has met it. The number of students who got score above 75 was $81.14 \%$. It was more than the criteria of success. However, none of the students reached a score of more than 84. To gain better improvement, it is not obligated to conduct the third cycle, but it is recommended that the students keep practicing even not in the classroom. 
When students are consistent with listening to English speakers' voices, they will be familiar with their normal speaking speed. Fast speech rate is a challenging factor in comprehending foreign language speech (Buck, 2001). Consistency of practicing while assisted by audio speed control application like ASC helps overcome the obstacles. The use of audio speed control applications is more effective than teachers who have to pronounce the contents of the recording at a slower tempo. When using audio speed control application, students also learn correct pronunciation from a native speaker. So, they are not bothered by new problems anymore. The usage of ASC in listening class offers a solution to meet students' needs. When students can only understand a recording in $70 \%$ of the speed, teachers should not play the recording at $100 \%$ speed. Playing a $100 \%$ speed rate recording several times does not help students with their problems because they cannot follow that speed rate.

Students slowly need adaptation to the level of the recording. Therefore teachers have to design strategies to address students' problems. According to Gilakjani, listening activities are recommended under students' needs (Gilakjani \& Sabouri, 2016). The presence of ASC application is very helpful for both teachers and students. They can set the speed based on the need very easily. When the students can follow the English native speaker recording only in 70\% - 80\% speed rate, they can set it in that level. Once the students' ability improves, the English teachers can increase the speed rate. The flexibility of Audio Speed Changer can overcome one challenging aspect in improving students' listening comprehension

Comparing to what Putra found in his research, this research does not solve tempo speed problems in a listening class by relying only on drilling technique (Putra, 2019). This research used media, namely ASC, to facilitate teachers and students to manage the recording speed based on students' ability. Managing the recording speed becomes important since repeating or drilling recording in a very vast tempo still makes the students difficult to follow the class. Meanwhile, setting the recording speed up by drilling it several times eases students to understand what the native speakers say in the recording. It, then, meets the target of listening comprehension.

ASC is a kind of support for students who cannot follow the class because of tempo speed problems. Notion in Liu argues that supports for students to reach learning targets become a temporary bridge. When students improve themselves until they meet the targets, they may remove the bridge (Liu, 2016). ASC may not be used when students do not have any problems with fast tempo anymore in a listening class.

\section{Conclusion}

Listening skill in foreign languages is challenging. To listen native speakers, language learners and teachers have to put efforts in providing the learning sources. Language learners cannot listen to foreign language spoken by a native speaker in daily life easily. On few occasions, they are surrounded by listening learning resources, like in the classroom, music or video platform, etc. They are unfamiliar with the native English speaker's voices. Thus, when they listen to different sounds and accents from theirs and when a fast tempo or speed accompanies it, it is no wonder they are confused because they feel so strange about what they hear.

One obstacle in the classroom is that the learners cannot clearly catch what native speakers say in the recording when it is played at normal speed. However, 
when the teacher speaks it at a slow speed, they can understand it. They need a longer time to listen carefully to the vocabulary spoken by native speakers. After that, they also need more time to process the meaning of the word they hear. For those reasons, the teacher uses Audio Speed Changer (ASC) application to overcome the problem.

ASC offers many advantages. ASC is an application that allows its users to set the speed based on the needs. This application is very suitable to use in a listening class. The speed is various. It is easy to use since it can be downloaded on students android. The usage of ASC also supports autonomous learning in listening classes. Students can practice in any places and times. After teaching listening skills to students using it during two cycles, students show improvement in catching the meaning of what native speakers say in the recording. This application is recommended to use for foreign language learners to teach, including English teachers. In addition, students can take the initiative to use it themselves when facing problems in listening to foreign languages, particularly speed problem.

Considering the results of the study above, there are several suggestions to offer. The first is that the students have to keep practicing using ASC to be familiar with fast tempo recording. The second is that the teachers continue to train students to follow the ideal tempo speed of native speakers. The last is that other researchers can use the results of this study to conduct further research, so that contributions to English language teaching can develop greatly. Lecturers or practitioners may also create listening materials with various levels of speed to enrich teaching materials for listening course.

\section{References}

Abu-Snoubar, T. K. (2017). On The Relationship between Listening and Speaking Grades of AL-Balqa Applied University English as a Foreign Language Students. $\begin{array}{lll}\text { International Education } & \text { Studies, } & 130(12),\end{array}$ https://doi.org/10.5539/ies.v10n12p130

Amal, et all. (2019). Using English Movie with Delay and Non Delay Subtitle to Improve Listening Skill. Journal of Linguistics and English Teaching Studies, 1(1), 110. http://www.stainmajene.id/index.php/lets/article/view/13

Anggraini, N and Istiqomah, L. (2019). An Analysis of Pronunciation Errors of English Consonant Sounds Produced by English Department Students. Wacana Didaktika, 11(3), 41-46.

ASC. (2018). Audio Speed Changer. www.Audiospeedchanger.Com/. https://www.audiospeedchanger.com/

Bingol et al. (2014). Listening comprehension difficulties encountered by students in second language learning class. Journal of Educational and Instructional Studies in the World, 4(4), 25-30.

Buck, G. (2001). Assessing Listening. Cambridge University Press. https://doi.org/http://dx.doi.org/10.1017/CBO9780511732959

Cahyono, BY and Widiati, U. (2009). The Teaching of EFL Listening in the Indonesian Context: The State of the Art. TEFLIN Journal, 20(2), 194-211.

Gallagher, E. (2015). Building language skills. Part 1: Listening. UNO Internacional. https://mx.unoi.com/2015/10/21/building-language-skills-part-1-listening/

Gilakjani, A. P., \& Sabouri, N. B. (2016). Learners' Listening Comprehension Difficulties in English Language Learning: A Literature Review. English Language 
Teaching, 9(6), 123. https://doi.org/10.5539/elt.v9n6p123

Hornby, A. . (1995). Oxford Advanced Learner's Dictionary of Current English. Oxford University Press.

Kementrian Pendidikan dan Kebudayaan. (2017). Panduan Penilaian oleh Pendidik dan Satuan Pendidikan Atas. Kementerian Pendidikan dan Kebudayaan.

Kemmis \& Taggart. (1988). The Action Research Planner. Deakin University Press.

Liu, J. (2016). Adaptation of Authentic Materials in English Listening Comprehension Classes. Theory and Practice in Language Studies, 6(9), 1774. https://doi.org/10.17507/tpls.0609.08

Maisarah. (2016). The Importance of Listening Skill as the Foundation to a Good Communication. Diglossia, 7(2), 1-11.

Putra, W. H. (2019). Improving the Students' Listening Comprehension through Drill Technique. Teknosastik, 16(2), 49. https:/ / doi.org/10.33365/ts.v16i2.140

Renukadevi, D. (2014). The Role of Listening in Language Acquisition; the Challenges \& Strategies in Teaching Listening. International Journal of Education and Information Studies, 4(1), 59-63. http:/ / www.ripublication.com

Rost, M. (1991). Listening in Action. Prentice Hall.

Ulum, Ö. G. (2015). Listening: The Ignored Skill in EFL Context. International Journal of Humanities Social Sciences and Education (IJHSSE), 2(5), 72-76.

Underwood, M. (1989). Teaching listening. Longman.

Wolvin and Carolyn. (1982). Listening. W.C. Brown.

Wong, A. (2015). The Act of Listening: The processes involved in listening comprehension. Hirao School of Management Review, 5(October), 73-80. 